\title{
Reactivation of an Idle Lease to Increase Heavy Oil Recovery Through Application of Conventional Steam Drive Technology in a Low Dip Slope and Basin Reservoir in the Midway-Sunset Field, San Jaoquin Basin, California
}

\author{
Quarterly Report \\ July 1 - September 30, 1997

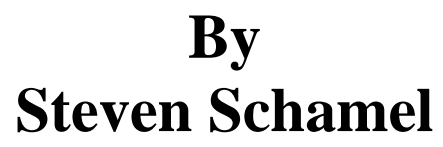

Work Performed Under Contract No.: DE-FC22-95BC14937

For

U.S. Department of Energy

Office of Fossil Energy

Federal Energy Technology Center

P.O. Box 880

Morgantown, West Virginia 26507-0880

By

Earth Sciences \& Resources Institute

At The University of Utah

423 Wakara Way

Suite 300

Salt Lake City, Utah 84108 


\section{Disclaimer}

This report was prepared as an account of work sponsored by an agency of the United States Government. Neither the United States Government nor any agency thereof, nor any of their employees, makes any warranty, express or implied, or assumes any legal liability or responsibility for the accuracy, completeness, or usefulness of any information, apparatus, product, or process disclosed, or represents that its use would not infringe privately owned rights. Reference herein to any specific commercial product, process, or service by trade

name, trademark, manufacturer, or otherwise does not necessarily constitute or imply its endorsement, recommendation, or favoring by the United States Government or any agency thereof. The views and opinions of authors expressed herein do not necessarily state or reflect those of the United States Government or any agency thereof. 
TITLE: REACTIVATION OF AN IDLE LEASE TO INCREASE HEAVY OIL RECOVERY THROUGH APPLICATION OF CONVENTIONAL STEAM DRIVE TECHNOLOGY IN A LOW DIP SLOPE AND BASIN RESERVOIR IN THE MIDWAY-SUNSET FIELD, SAN JAOQUIN BASIN, CALIFORNIA

Cooperative Agreement No.: DE-FC22-95BC14937

Contractor Name and Address: Earth Sciences \& Resources Institute at the University of Utah, 423 Wakara Way, Suite 300, Salt Lake City, UT 84108

Date of Report: February 27, 1998

Award Date: June 14, 1995

Anticipated Completion Date: March 13, 2000

Government Award for Current Budget Period: \$1,531,520.83

Principal Investigator: Steven Schamel

Project Manager: Edith C. Allison, National Petroleum Technology Office

Reporting Period: July 1- September 31, 1997

\section{Objective}

A previously idle portion of the Midway-Sunset field, the ARCO Western Energy Pru Fee property, is being brought back into commercial production through tight integration of geologic characterization, geostatistical modeling, reservoir simulation, and petroleum engineering. This property, shut-in over a decade ago as economically marginal using conventional cyclic steaming methods, has a 200-300 foot thick oil column in the Monarch Sand. However, the sand lacks effective steam barriers and has a thick watersaturation zone above the oil-water contact. These factors require an innovative approach to steam flood production design that will balance optimal total oil production against economically viable steam-oil ratios and production rates. The methods used in the Class III demonstration are accessible to most operators in the Midway-Sunset field and could be used to revitalize properties with declining production of heavy oils throughout the region.

The 40 ac Pru Fee property is located in the super-giant Midway-Sunset field and produces from the late Miocene Monarch Sand, part of the Monterey Formation. The Midway-Sunset field was discovered prior to 1890. Cumulative production from the field through 1995 was 2.3 billion barrels of oil and 563 billion cubic feet of gas, with remaining reserves estimated to exceed $450 \mathrm{MMBO}$. The average daily field production in 1995 was 163,400 barrels of oil. In the Pru Fee property, now held by ARCO Western Energy, cyclic steaming was used to produce $13^{\circ}$ API oil. However, the previous 
operator was unable to develop profitably this marginal portion of the Midway-Sunset field using standard enhanced oil recovery technologies and chose rather to leave more than 3.0 MMBO of oil in the ground that otherwise might have been produced from the 40 ac property. Only 927 MBO had been produced from the property when it was shut-in in 1987. This is less than $10 \%$ of the original oil-in-place, which is insignificant compared to typical heavy oil recoveries in the Midway-Sunset field of 40 to $70 \%$. The objective of the demonstration project is to encourage a similar incremental increase in production in all other marginal properties in the Midway-Sunset and adjacent fields in the southern San Joaquin Basin.

In January 1997 the project entered its second and main phase with the purpose of demonstrating whether steamflood can be a more effective mode of production of the heavy, viscous oils from the Monarch Sand reservoir than the more conventional cyclic steaming. The objective is not just to produce the pilot site within the Pru Fee property south of Taft (Figure 1), but to test which production parameters optimize total oil recovery at economically acceptable rates of production and production costs.

\section{Stratigraphic Characterization}

\section{General Statement}

The Midway-Sunset field produces oil from multiple reservoirs that range in age from Oligocene to Pleistocene. However, most of the production is from the Upper Miocene sand reservoirs (Hall and Link, 1990). Production at the ARCO Western Energy (AWE) Pru Fee property is from the Upper Miocene Monarch sand. At the 8 ac Pru pilot demonstration site, in the center of the Pru Fee property (Fig. 1), the average depth to the Monarch sand is 1,099 feet (Table 1).

The stratigraphic nomenclature applied to this part of the Midway-Sunset field is a combination of formal units (which are recognized at the surface and in the subsurface) and informal units, which are mostly identified in the subsurface. The stratigraphic nomenclature of Foss and Blaisdell (1968), Reid (1990), Nilsen (1996), and Sturm (1996) has been adopted in for this project as it most closely reflects that used by the petroleum industry.

The Monarch sand is one of several sand lenses within the Belridge Diatomite Member of the Monterey Formation (Fig. 2). It overlies the informal Republic, Williams, and Leutholtz sands (in descending order) of the Antelope Shale. The Reef Ridge Shale overlies the Monarch in other portions of the Midway-Sunset field. However, a regional Pliocene unconformity, referred to as the sub-Etchegoin unconformity (Sturm, 1996), truncates the Reef Ridge Shale and the top of the Belridge Diatomite Member at the Pru site. Here the Pliocene Etchegoin Formation rests with a low angle unconformity on the Monarch sand and an overlying Belridge Diatomite Member mudstone unit. The base of the Monarch Sand lens has not been penetrated at the Pru site. Its total thickness and relationship to underlying mudstones in the Belridge Diatomite Member are not known. However, the Monarch Sand is known to be at least $320 \mathrm{ft}$ thick at the TO-2 well. 


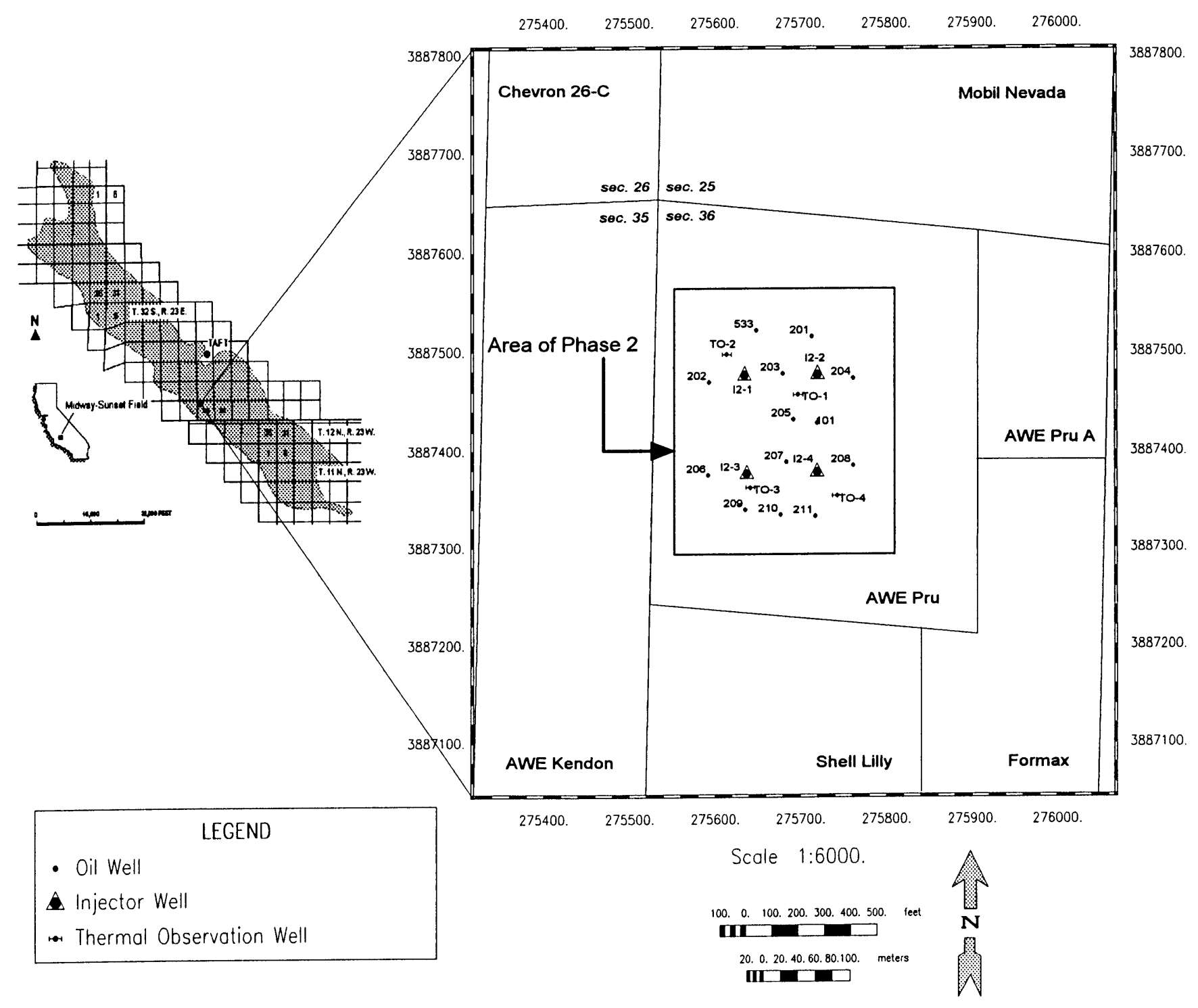

Figure 1. The Pru project encompasses the AWE Pru and adjacent leases. Wells used for the stratigraphic characterization in Phase 2 are within the AWE Pru lease. Map coordinates are in UTMs, zone 11. 


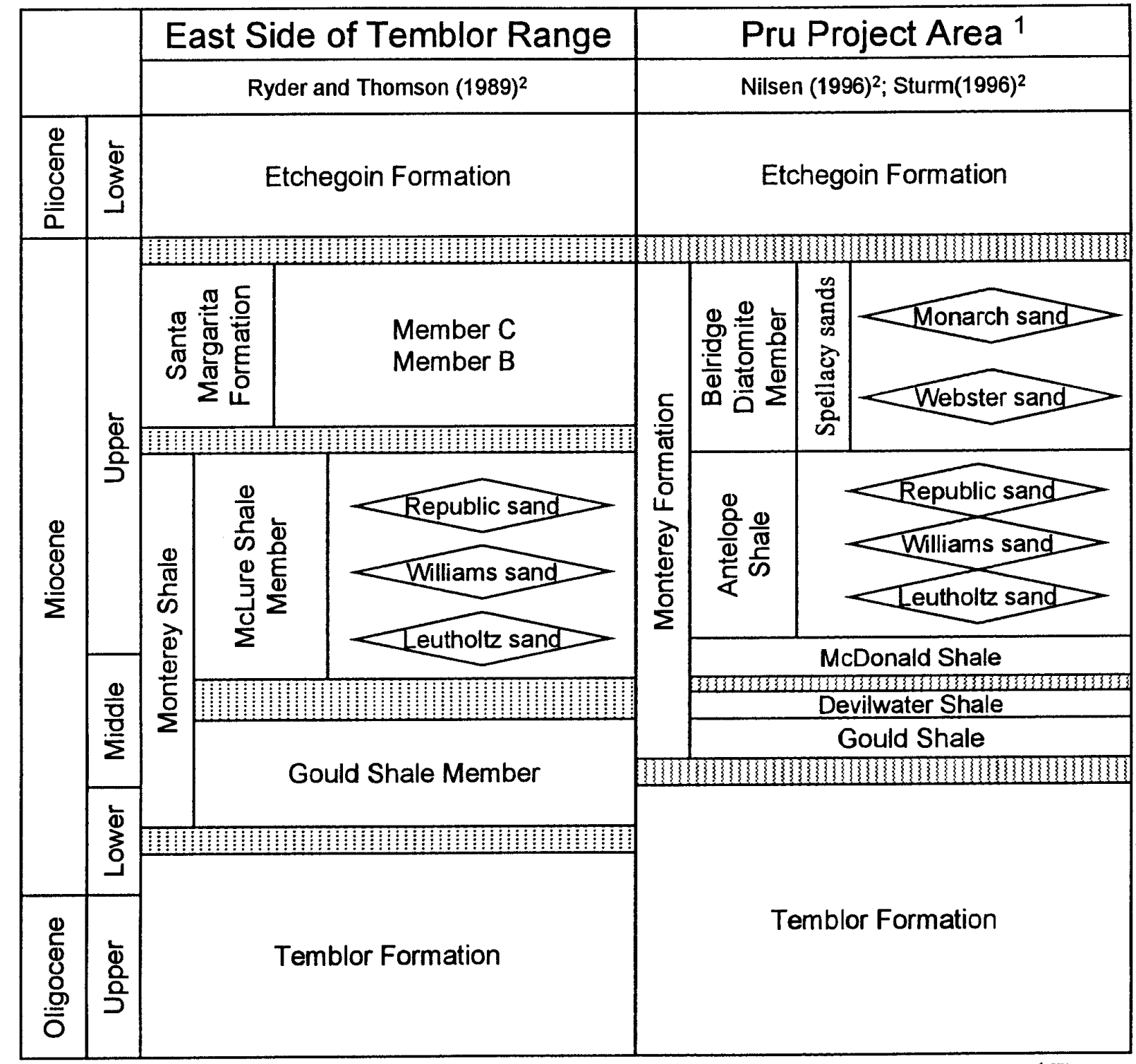

Figure 2. Stratigraphic table of formations in the Pru project area and east side of the Temblor Range. ${ }^{1}$ The Monarch sand is the oldest formation penetrated in the Pru project area. 2 Modified for the Pru project area 


\section{Stratigraphic Modeling of the Monarch Sand}

The Monarch Sand at the Pru pilot site has been characterized using petrophysical logs from the 18 new wells drilled in January-March, 1997 and petrophysical logs, core descriptions, and petrophysical data from 3 older wells (Pru 101, Pru TO-1, and Pru 533) (Fig. 1). The two wells in the Pru property with nearly continuous core through the Monarch Sand, Pru 101 and Pru 533, provided the basis for calibrating log response with lithology and petrophysical properties (Fig. 3) and for testing the validity of log-based bed-scale stratigraphic correlation.

The Monarch Sand is relatively homogeneous and is dominated by thin-bedded, poorly to very poorly sorted, medium- to coarse-grained sandstone. Characteristically, medium-grained sand, coarse-grained sand, granule sand, and pebble sand form graded beds and sand-on-sand bed successions one to several $\mathrm{ft}$ in thickness. The sand packages periodically are punctuated by diatomaceous mudstone and muddy bioturbated finegrained sand. Cobble-size clasts (granite, gneiss and schist) up to 18 in diameter are observed in core and noted in logs by a high gamma spikes associated with abnormally low log porosity values. The overall lithological characteristics of the Monarch Sand are those of a proximal turbidite as described by Bouma (1962), Mutti and Ricci-Lucchi (1972; 1975), Walker and Mutti (1973), and Bouma et al. (1985). The stacking patterns, coarsening upward grain size, and a general coarse-grained nature of the highly graded beds can be interpreted as a progradational turbidite sequence (Walker, 1981). Refer to the 1995-96 annual report for a detailed description by Creties Jenkins of the Pru 101 core and lithofacies within the Monarch Sand.

In general, the sandy lithofacies present within the Monarch Sand alternate at a scale of a few feet or less and exhibit similar electrical log responses. This makes it virtually impossible to reliably distinguish a poorly sorted medium-grain sand from a course-grain sand. Only the two extreme lithofacies, diatomaceous mudstone and the pebbly sand, can be interpreted with any confidence from the logs. Both of these lithofacies are characterized by high gamma log values. In addition, they exhibit the two extremes in density porosity. The mudstone lithofacies consistently is associated with log porosity values greater than $35 \%$, whereas pebbly sand lithofacies generally has log porosity values less than $26 \%$. In the wells for which core is not available, these two lithofacies are determined from a combination density porosity and gamma ray logs. All other intervals are merely the "sand" lithofacies undivided. Even though the wells are very closely spaced and the log suites are comparable, only the mudstone lithofacies could be correlated with any degree of reliability. The pebbly sand lithofacies is either too limited in lateral extent or too variable in log properties to be correlated as discrete layers. Only broadly delimited intervals in which this lithofacies was present could be carried through a few adjacent wells.

The mudstone lithofacies, significant as a potential barrier or baffle to steamflood, was recognizable less as discrete beds that could be correlated from well to well than as a dominant lithologic element within a stratigraphic interval of limited areal extent. Only one such interval, referred to as the "Middle Marker Unit", exhibited continuity across nearly the entire pilot site. The presence of this marker unit, just 5-15 ft in thickness, 


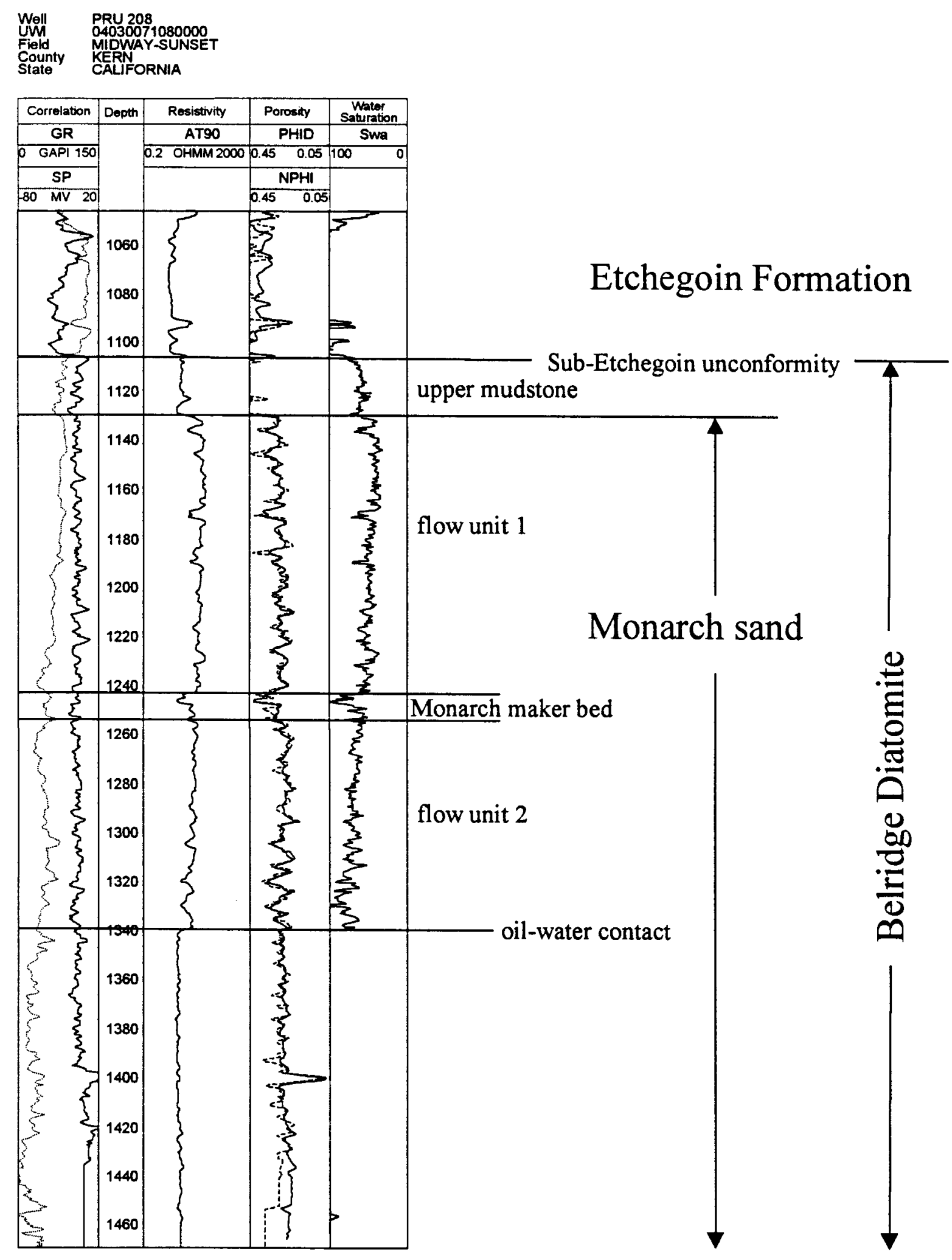

Figure 3. Type log of the Monarch sand of the Belridge Diatomite Member of the Monterey Formation. Muddy lithofacies are interpreted as beds that have porosity greater than 35 percent. The upper mudstone is interpreted as Belridge Diatomite mud which depositionally overlies the Monarch sand This formation is probably a steam barrier. The Monarch marker bed is interpreted as a mudstone that is a local steam baffle. 
provides a basis to divide the Monarch Sand into three stratigraphic elements - an Upper Sand, the Middle Marker, and a Lower Sand.

Even with the high density of quality log suites from the 20 wells drilled expressly for this project, it proved impossible to develop a multi-layer stratigraphic model for the Monarch Sand at this location. The apparent absence of lateral continuity and limited variation in log responses between the lithofacies observed in core severely limit highresolution stratigraphic modeling of this sand reservoir at this site.

The previous stratigraphic model of the Monarch Sand developed in first phase of the project, which was based mainly on resistivity curves, has been substantially revised. It is now clear that the various correlation surfaces developed in that older model are ungrounded. Only the "Surface 3" correlation, which corresponds to the base of the "Middle Marker Unit" in the current model, is valid. Unfortunately, no further correlation within the Monarch Sand are possible at the site of the Pru pilot demonstration.

In the southeastern half of the pilot site, the Monarch Sand is overlain by a diatomaceous mudstone, presumably the enclosing Belridge Diatomite Member, which is erosionally beveled and absent beneath the base Etchegoin unconformity towards the northwest. This mudstone also is delineated on the basis of gamma ray and porosity log response (Figure 3). The Etchegoin Formation, however, is easily recognized in resistivity logs, as is the oil-water contact within the Monarch Sand.

\section{Subsurface Configuration of the Monarch Sand}

The four structural cross sections and two structure contour maps presented here depict the subsurface configuration of the Monarch Sand. Each cross section (Fig. 4 through Fig. 7) shows the Etchegoin Formation, the base Etchegoin unconformity, and the Monarch Sand all dipping southeastward. The southeastern dip also is clear in the structure contour maps (Fig. 8 and Fig. 9). The base Etchegoin unconformity dips approximately $8^{\circ} \mathrm{SE}$, whereas the underlying Monarch Sand dip is slightly steeper, about $16^{\circ} \mathrm{SW}$. The sub-Etchegoin unconformity bevels northwestward across both the Belridge Diatomite mudstone above the Monarch Sand and higher portions of the "Upper Sand Unit".

The upper Belridge Diatomite mudstone is identified in wells in the southern and southeastern part of the part of the pilot site, where it reaches a maximum thickness of 33 $\mathrm{ft}$. It is absent beneath the base Etchegoin unconformity to the northwest (Fig. 4 through Fig. 7). A second mudstone-dominated layer, the "Monarch Marker Unit", is identified in most wells, except those in the extreme northwest. This broadly defined muddy unit thins from a maximum of 22 feet in the southeastern part of the pilot site northwestward to be cut out by the "Upper Sand Unit" as shown in Fig. 9. Northwest of the limit of the "Monarch Marker Unit" the Monarch Sand cannot be divided reliably on the basis of log interpretation. 


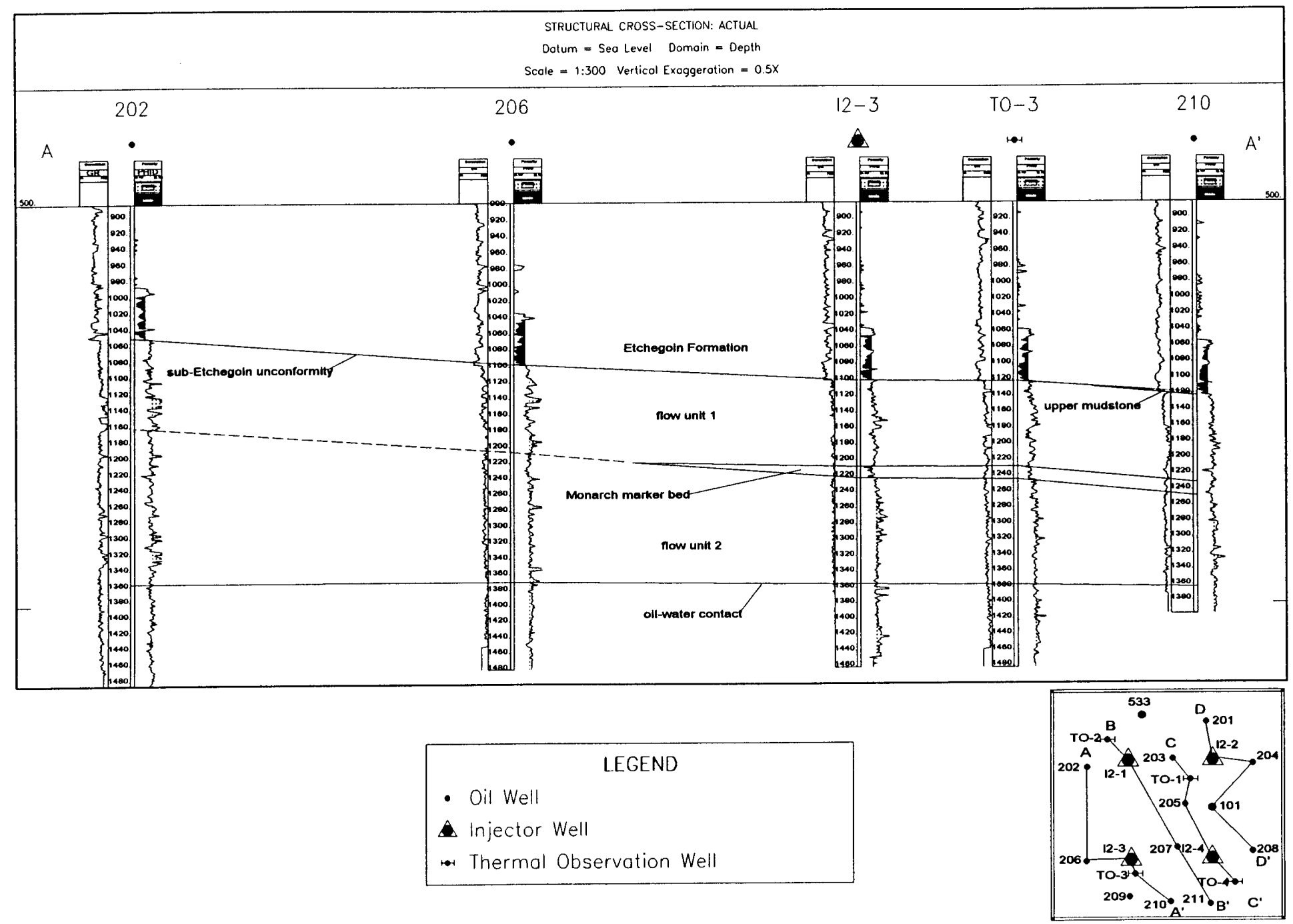

Figure 4. Structural cross section A-A'. The Monarch sand underlies the sub-Etchegoin unconformity and consists of the upper mudstone, flow unit 1 , the Monarch marker bed, and flow unit 2 . These units dip about $16^{\circ}$ southeast and the overlying Etchegoin Formation dips about $8^{\circ}$ southeast. The gamma ray curve is on the left and the density porosity curve is on the right. Porosity over 35 percent is blackened to the left and porosity less than 26 percent is stippled to the right. 


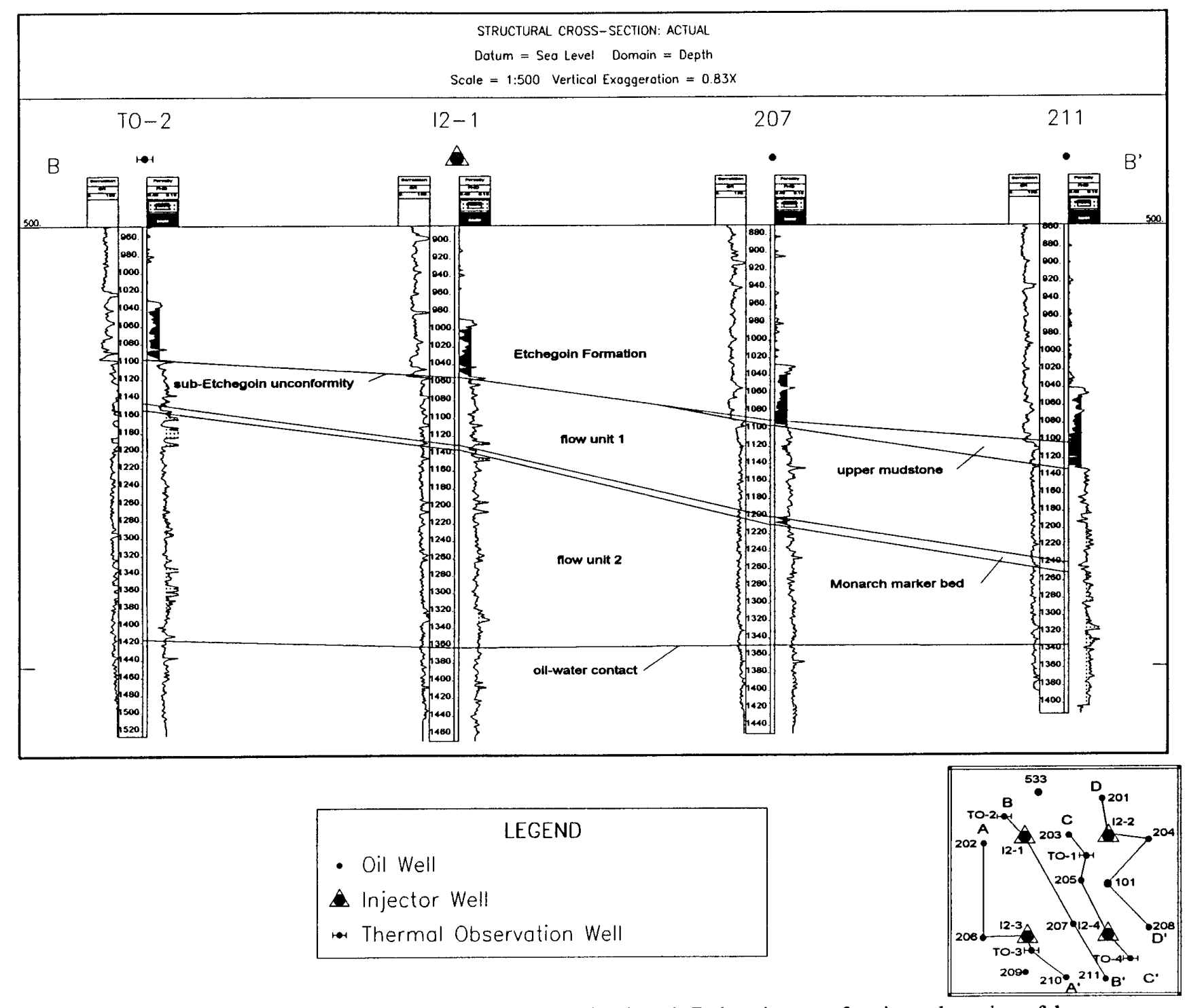

Figure 5. Structural cross section B-B'. The Monarch sand underlies the sub-Etchegoin unconformity and consists of the upper mudstone, flow unit 1 , the Monarch marker bed, and flow unit 2. These units dip about $16^{\circ}$ southeast and the overlying Etchegoin Formation dips about $8^{\circ}$ southeast. The gamma ray curve is on the left and the density porosity curve is on the right. Porosity over 35 percent is blackened to the left and porosity less than 26 percent is stippled to the right. 


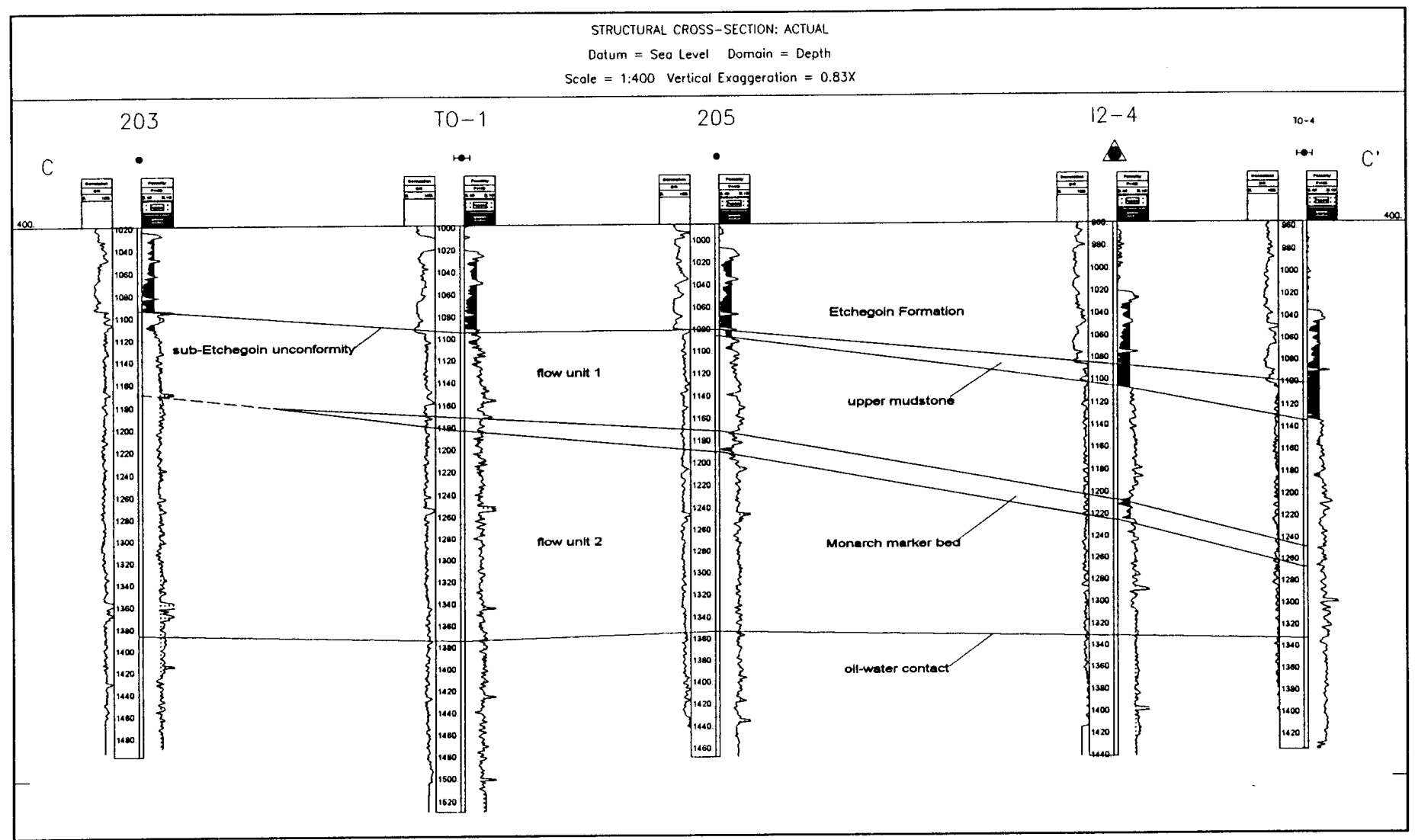

LEGEND
- Oil Well
- Injector Well
- Thermal Observation Well

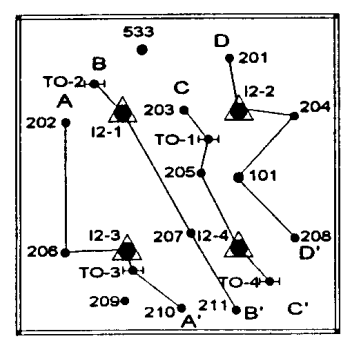

Figure 6. Structural cross section C-C'. The Monarch sand underlies the sub-Etchegoin unconformity and consists of the upper mudstone, flow unit 1 , the Monarch marker bed, and flow unit 2 . These units dip about $16^{\circ}$ southeast and the overlying Etchegoin Formation dips about $8^{\circ}$ southeast. The gamma ray curve is on the left and the density porosity curve is on the right. Porosity over 35 percent is blackened to the left and porosity less than 26 percent is stippled to the right. 


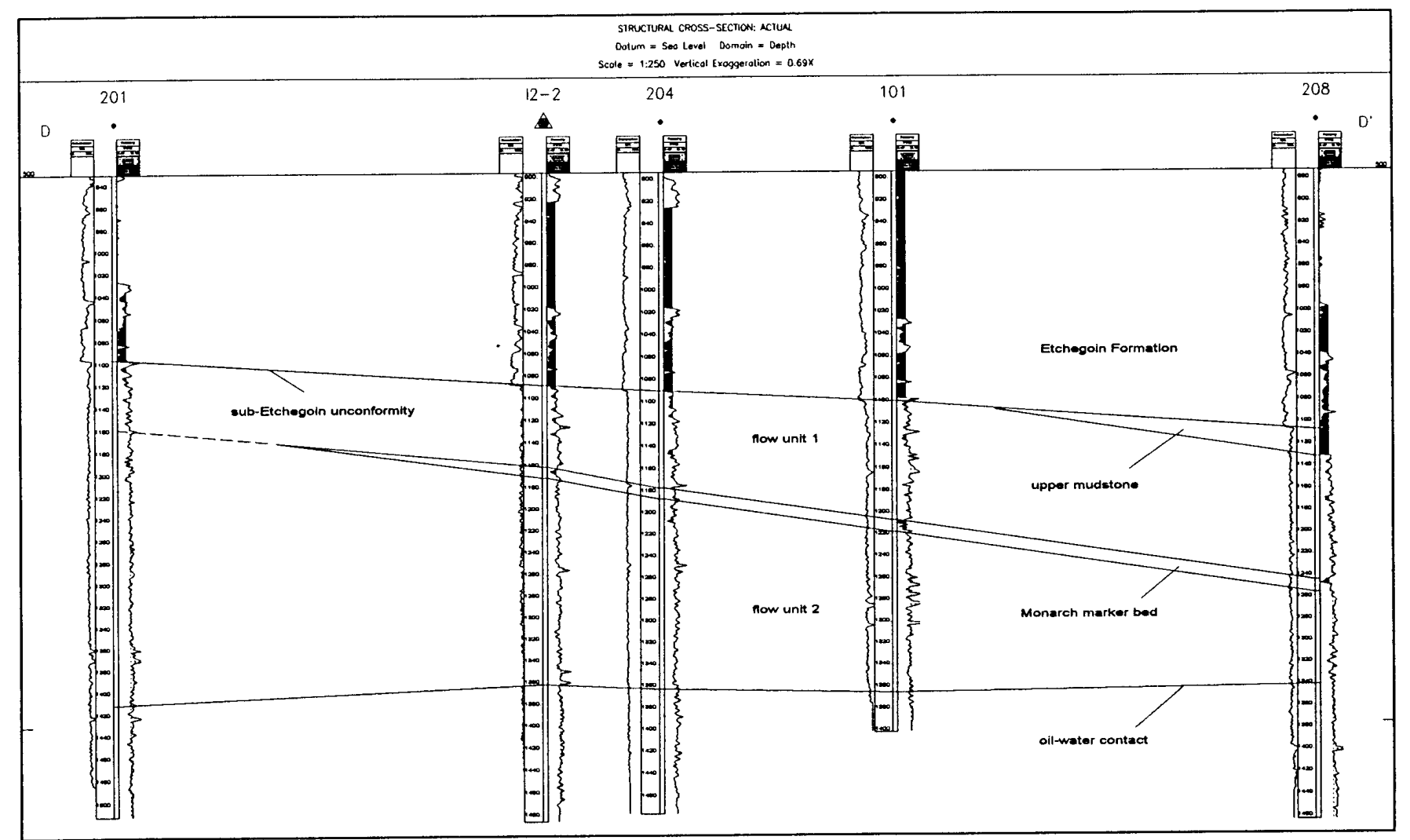

\begin{tabular}{l} 
LEGEND \\
- Oil Well \\
Injector Well \\
\hline
\end{tabular}

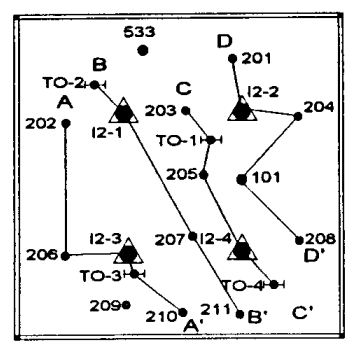

Figure 7. Structural cross section D-D'. The Monarch sand underlies the sub-Etchegoin unconformity and consists of the upper mudstone flow unit 1 the Monarch marker bed and flow unit 2. These units dip about $16^{\circ}$ southeast and the overlying Etchegoin Formation dips about $8^{\circ}$ southeast. The gamma ray curve is on the left and the density porosity curve is on the right. Porosity over 35 percent is blackened to the left and porosity less than 26 percent is stippled to the right. 


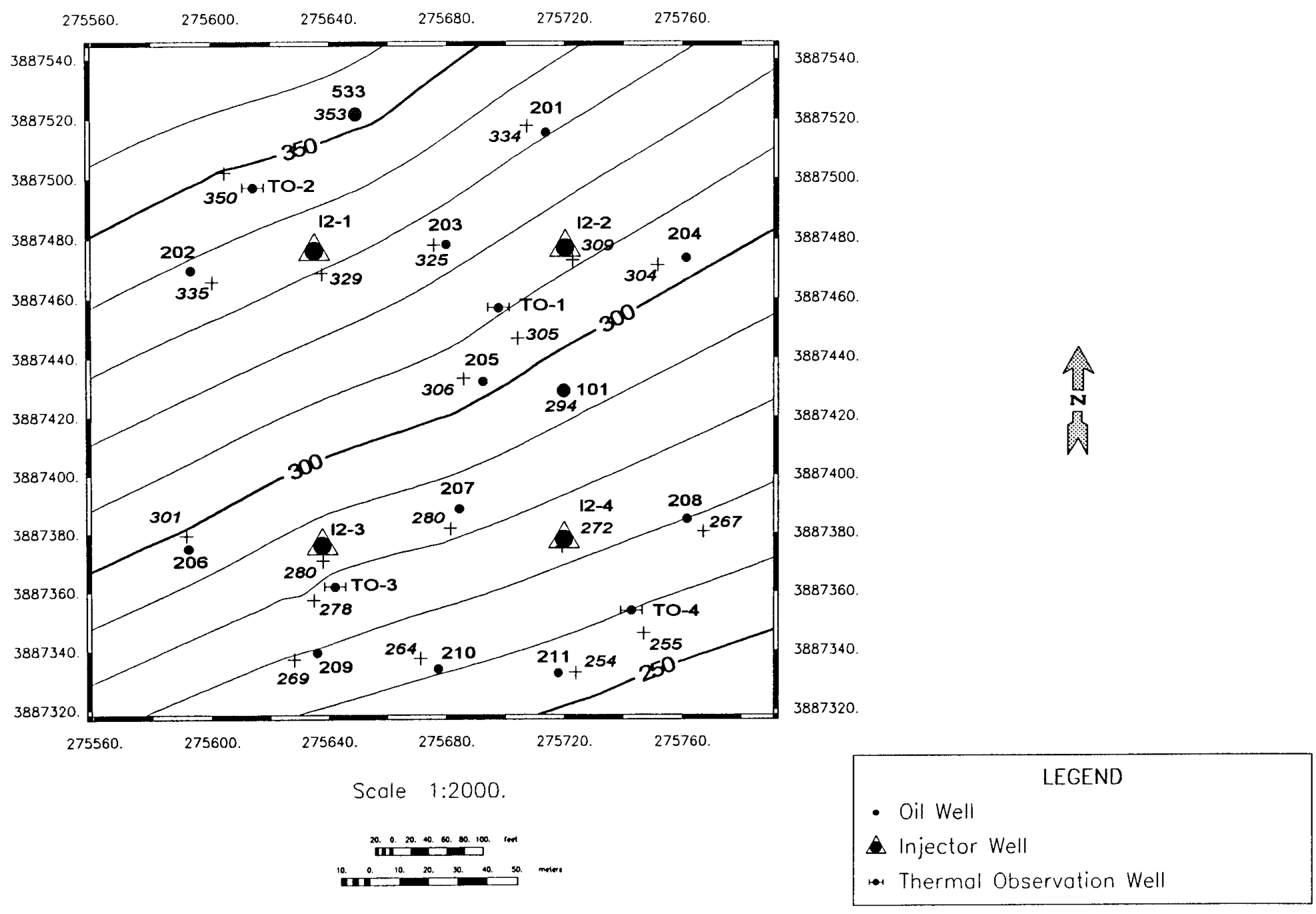

Figure 8. Structure contour map on the sub-Etchegoin unconformity. The unconformity and overlying Etchegoin Formation dips about $8^{\circ}$ southeast. The italic numbers are the subsea values (in feet) for the sub-Etchegoin unconformity. The plus symbol indicates the down hole location of the top of the sub-Etchegoin unconformity. The contour interval is 10 feet. Map coordinates are in UTMs, zone 11 . 


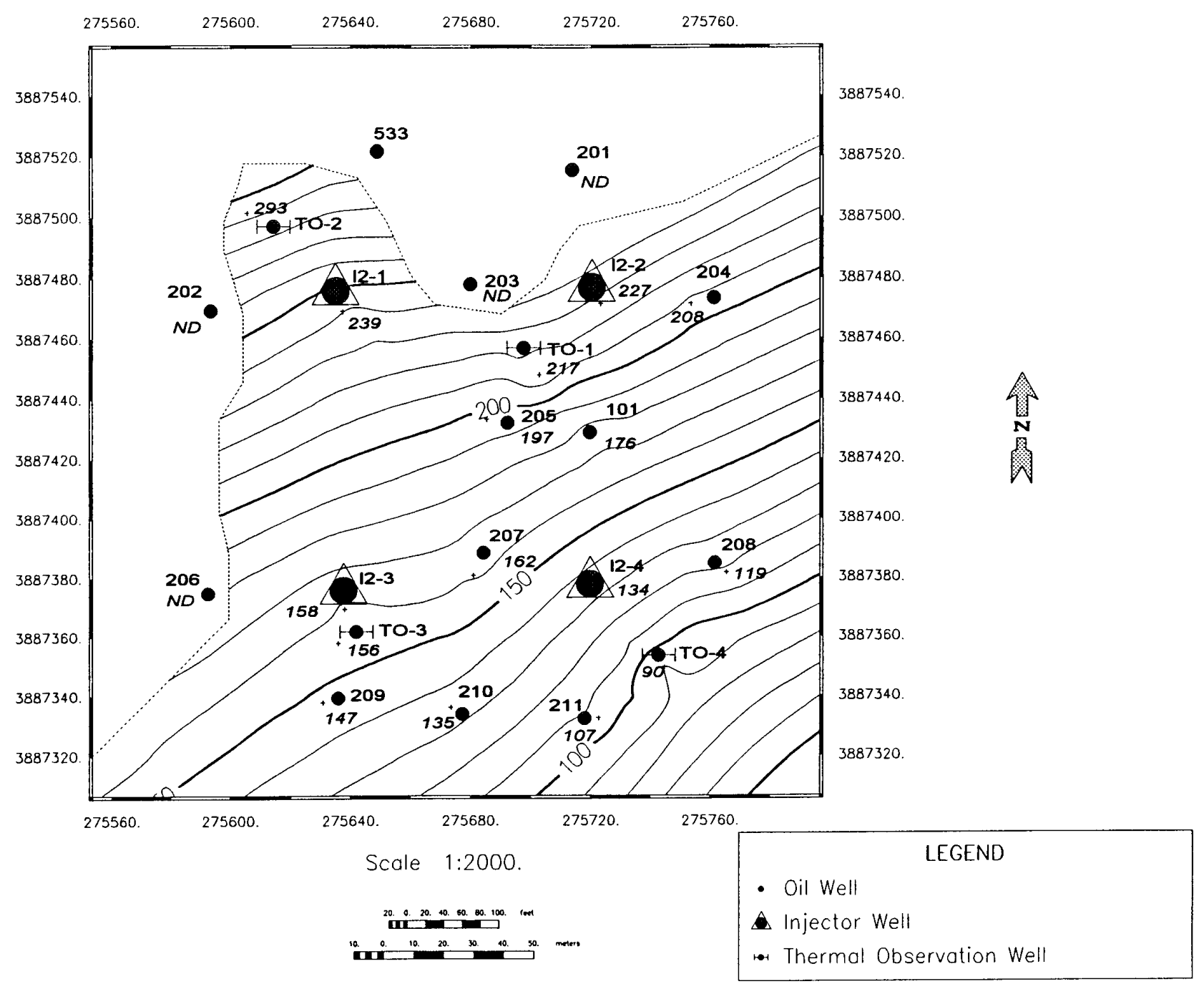

Figure 9. Structure contour map on the base of the Monarch marker bed. The Monarch marker bed pinches out or is scoured out by the overlying flow unit 1 in the northwest part of the study area. The dashed line represents the approximate limit of the Monarch marker bed. The italic numbers are the subsea values (in feet) for the base of the Monarch marker bed and ND represents where the base of the Monarch marker bed is missing. The plus symbol indicates the down hole location of the base of the Monarch marker bed The contour interval is 10 feet. Map coordinates are in UTMs, zone 11 
The sub-Etchegoin unconformity and upper mudstone are interpreted as steam barriers and the Monarch marker bed is interpreted as a baffle. Steam should be effectively contained along the barriers; however, steam will probably migrate in the updip direction along the base of the Monarch Marker Unit and then upward where this unit is missing.

The oil-water contact (Fig. 8) was penetrated in all of the 20 wells. It is generally subplanar and horizontal, 20 to 40 feet above sea level as depicted on the cross sections (Fig. 4 through Fig. 7). This configuration and depth are consistent the oil-water contact mapped in an earlier phase of the project across a considerably larger area using a different set of wells.

The gross pay of the Monarch Sand is defined as the oil saturated interval between the base Etchegoin unconformity and the oil-water contact (OWC) in the northwest and between the base of the upper Belridge Diatomite mudstone and the OWC in the southeast. The gross pay thins southeastward from approximately $300 \mathrm{ft}$. to just $200 \mathrm{ft}$ due to the southeastern dip of the reservoir through the OWC and the insertion of the Belridge Diatomite mudstone above the Monarch Sand.

The stratigraphy and structure of the Monarch reservoir at the pilot site is consistent regionally with the stratigraphy and structure of the Monarch Sand as described by Sturm (1996).

\section{References Cited}

Bouma, A. H., 1962, Sedimentology of some flysch deposits, a graphic approach to facies interpretation: Elsevier Company, Amsterdam, 168 p.

Bouma, A. H., Barnes, N. E., and Normark, W. R., 1985, Submarine fans and related turbidite sequences, frontiers in sedimentary geology: Springer-Verlag, New York, $351 \mathrm{p}$.

Foss, C. D., and Blaisdell, R., 1968, Stratigraphy of the west side southern San Joaquin Valley, Guidebook to Geology and Oil Fields of the West Side Southern San Joaquin Valley: American Association of Petroleum Geologists, Society of Economic Geophysicists, and Society of Economic Paleontologists and Mineralogists, Pacific Sections, Annual Field Trip, p. 33-43.

Hall, B. R., and Link, M. H., 1990, Reservoir description of a Miocene turbidite sandstone, Midway-Sunset Field, California, in Barwis, J. H., McPherson, J. G., and Studlick, J. R. J., eds., Sandstone Petroleum Reservoirs: Springer-Verlag, New York, p. 509-533. 
Mutti, E., and Ricci-Lucchi, F., 1972, translation by T.H. Nilsen (1978), Turbidites of the northern Appenines: Introduction to facies analysis: American Geological Institute, Reprint Series 3, p. 127-166.

Mutti, E., and Ricci-Lucchi, F., 1975, The significance of certain sequential units in turbidite series: Society Geological of France Bulletin 16, v. 6, p. 577-582.

Nilsen, T. H., 1996, Regional geology of the southwestern San Joaquin Basin, California, in Nilsen, T. H., Wylie, Jr., A. S., and Gregory, G. J., eds., Geology of the Midway-Sunset Oil Fields: AAPG Field Trip Guidebook, p. 7-38.

Reid, S. A., 1990, Trapping characteristics of upper Miocene turbidite deposits, Elk Hills Field, Kern County, California, in Kuespert, J. G., and Reid, S. A., eds., Structure, stratigraphy and hydrocarbon occurrences of the San Joaquin Basin, California: Society of Economic Paleontologists and Mineralogists Pacific Section Field Trip Guidebook, 64 p.

Ryder, R. T., and Thomson, A., 1989, Tectonically controlled fan delta and submarine fan sedimentation of the Late Miocene age, southern Temblor Range, California: U.S. Geological Survey Professional Paper 1442, 59 p.

Schamel, S., Forster, C., Deo, M., Swain, R., Simmons, M., Sprinkel, D., and Adams, R., 1996, Integrated, multidisciplinary reservoir characterization, modeling, and engineering leading to enhanced oil recovery from the Midway-Sunset field, California [abs]: American Association of Petroleum Geologists Official Program, San Diego, California, May 19-22, 1996, p. 125.

Sturm, D. H., 1996, Spellacy reservoirs sandstones, Midway-Sunset Field, in Nilsen, T. H., Wylie, Jr., A.S., and Gregory, G. J., eds., Geology of the Midway-Sunset Oil Fields: AAPG Field Trip Guidebook, p. 155-174.

Walker, R. G., 1981, Turbidites and associated coarse clastic deposits, in Walker, R. G., ed., Facies Models: Geoscience Canada Reprint Series 1, p. 91-104.

Walker, R. G., and Mutti, E., 1973, Turbidite facies and facies associations, in Middleton, G. V., and Bouma, A. H., eds., Turbidites and Deep Water Sedimentation: Society of Economic Paleontologists and Mineralogists Pacific Section, Short Course Notes, Los Angeles, p. 119-157. 